\title{
AFFECTIVE-COGNITIVE CONSISTENCY OF ATTITUDE AS A MODERATOR OF THE JOB SATISFACTION-PERFORMANCE RELATIONSHIP
}

\author{
DELÉNE VISSER \\ SANET COETZEE \\ Department of Industrial and Organisational Psychology \\ University of South Africa
}

\begin{abstract}
Past research has often shown that job satisfaction and job performance are uncorrelated. The current study was an attempt to clarify the relationship by examining the role of affective-cognitive consistency (ACC) to test whether attitudinal consistency affects the strength of the relationship. A secondary objective was to assess whether modified versions of the Overall Job Satisfaction Scale (OJS) and the Minnesota Satisfaction Questionnaire (MSQ), administered to 166 full-time employees from a variety of companies, may be regarded as affective and cognitive measures of job satisfaction respectively. This view was supported by means of exploratory and confirmatory factor analytic results. Overall job satisfaction was measured by a composite of the modified OJS and MSQ, and job performance was rated on a 10-point scale by the employees' supervisors.

Respondents' scores on the modified OJS and MSQ were then used to form groups that were high or low in ACC. For employees who displayed high ACC regarding their job satisfaction attitudes, medium to large positive correlations between the job satisfaction measures and performance were obtained. In contrast, non-significant correlations were recorded for the low ACC groups. The hypothesis that ACC is a significant moderator of the relationship between job satisfaction and job performance was therefore supported.
\end{abstract}

\section{OPSOMMING}

Vorige navorsing het dikwels getoon dat werktevredenheid en werkprestasie nie korreleer nie. Dié ondersoek was 'n poging om lig te werp op hierdie verwantskap deur die rol van affektiewe-kognitiewe konsekwentheid (AKK) te ondersoek ten einde te toets of houdingkonsekwentheid die sterkte van die verwantskap beinvloed. 'n Sekondêre doelwit was om te bepaal of gewysigde weergawes van die Overall Job Satisfaction Scale (OJS) en die Minnesota Satisfaction Questionnaire (MSQ), toegepas op 166 voltydse werknemers van 'n verskeidenheid ondernemings, as affektiewe en kognitiewe metings van werktevredenheid respektiewelik, beskou kan word. Hierdie beskouing is ondersteun deur ondersoekende en bevestigende faktoranalitiese resultate. Algemene werktevredenheid is gemeet deur 'n kombinasie van die gewysigde OJS en MSQ en werkprestasie is beoordeel op 'n 10-punt skaal deur die werknemers se toesighouers.

Respondente se tellings op die gewysigde OJS en MSQ is hierna gebruik om groepe te vorm wat hoog of laag in terme van AKK was. Vir werknemers met hoë AKK betreffende hul werktevredenheidhoudings is medium tot hoë positiewe korrelasies tussen die werktevredenheidmetings en prestasie behaal. In kontras hiermee is onbetekenisvolle korrelasies vir die lae AKK-groepe aangeteken. Die hipotese dat AKK 'n beduidende moderator van die verwantskap tussem werktevredenheid en werkprestasie is, is dus ondersteun.

It is commonly accepted that job satisfaction is one of the most widely researched variables in the field of Industrial and Organisational Psychology (Baker, 2004; Hoole \& Vermeulen, 2003; Pretorius \& Roodt, 2004). The interest in job satisfaction can generally be attributed to the relevance of job satisfaction to the physical and mental well-being of employees (Hoole \& Vermeulen, 2003), because current studies suggest that the well-being of employees is in the best interest of the employer (Harter, Schmidt \& Keyes, 2003). Furthermore, the preoccupation with job satisfaction can be attributed to its expected importance in relation to various employee workplace responses (Baker, 2004). For instance, job satisfaction has been examined extensively as a predictor of employee absenteeism (Scott \& Taylor, 1985) and turnover (Cotton \& Tuttle, 1986). Harter, Schmidt and Keyes (2003) have shown that job satisfaction, commitment, joy, fulfillment, interest and caring is evidence of positive affect and that the experience of positive affect in the workplace relates to efficient work, employee retention, creativity and, ultimately, business outcomes. In particular, researchers have studied the relationship between individual-level job satisfaction and individual-level performance (Iaffaldano \& Muchinsky, 1985; Judge, Thoresen, Bono \& Patton, 2001) and, more recently, the relationship between unit-level job satisfaction and financial and organisational performance (Harter, Schmidt \& Hayes, 2002; Schneider, Hanges, Smith \& Salvaggio, 2003).

Requests for copies should be addressed to: D Visser, jdv@rau.ac.za
Much research has been done on the relationship between job satisfaction and performance (Schleicher, Watt \& Greguras, 2004), but the study of this relationship has been described as having a controversial history (Saari \& Judge, 2004). Early studies concluded that the relationship between job satisfaction and performance was trivial (Iaffaldano \& Muchinsky, 1985), but this conclusion was contradicted by further research (Isen \& Baron, 1991; Moorman, 1993). In response to these contradictory findings, Bassett (1994) concluded that it cannot be assumed that satisfied employees will be productive employees, nor can it be assumed that job satisfaction is the result of good job performance.

In examining the relationship between job satisfaction and performance, many studies focused on the nature and measurement of performance indicators as a possible explanation for the varying results obtained across investigations (Schleicher, Watt \& Gregarus, 2004). For instance, Spector's (1997) review suggested that satisfied employees are more cooperative, more helpful to their colleagues, more punctual and time efficient, report for more days of work and stay with the company longer than unsatisfied employees. After a more recent and comprehensive review of 301 studies, Judge et al. (2001) argued that the satisfaction-performance relationship should be studied from another angle. They strongly recommended that moderators of the satisfactionperformance relationship should be studied in order to understand better the conditions under which these variables are related. A further possibility for research was 
suggested by Schleicher et al. (2004) who noted that the conceptualisation and measurement of job satisfaction in investigating this relationship should be clarified.

Job satisfaction is a complex variable (Rothmann, 2001). There has been some debate over the extent to which job satisfaction represents a stable orientation or a disposition (Schleicher et al., 2004). Job satisfaction can also be defined as an attitude (Steel \& Rentsch, 1997). Consequently, Saari and Judge (2004) argued that job satisfaction is, from the perspective of research and practice, the most focal employee attitude. Attitude research emerged as a significant part of the social sciences during the first decades of the 20th century (Kraus, 1995). Kraus (1995) postulated that the most fundamental assumption underlying the attitude concept, is the notion that attitudes guide, influence, direct, shape, or predict actual behaviour. Orban and Harris (1998) also found what researchers had long speculated about, namely that employee attitudes are related to organisational outcomes, even to robust measures of unit performance. It appears that researchers have become increasingly optimistic about the attitude-behaviour relationship since the late sixties (Kraus, 1995). Despite this, skepticism about the magnitude of attitude-behaviour correlations continued and there was a growing sense that inconsistency between attitudes and behaviour was more common than previously thought (Kraus, 1995). One set of explanations for the apparent inconsistency between attitudes and behaviour is the argument that the level of consistency depends on, or is moderated by other variables (Kraus, 1995).

It has been proposed that attitudes have an affective component (a positive or negative feeling toward the issue) and a cognitive component (beliefs or thoughts about the issue) (Rosenberg, 1960). Rosenberg (1968) stated that when the affective and cognitive components of an attitude are mutually consistent, the attitude is in a stable state. In other words, the strength of an attitude is determined by more than just the favourability of the attitude. This means that the strength of an attitude is influenced by the consistency or agreement between the affective and cognitive components of the attitude. Consistency between these two components is typically considered to be indicative of stable attitudes that tend to be better predictors of behaviour than the attitudes of individuals with low affective-cognitive consistency (ACC) (Norman, 1975). Therefore, researchers have proposed that affective-cognitive consistency is a moderator of the attitudebehaviour relationship that may shed light on the inconsistent findings regarding the relationship thus far. Kraus (1995) and also Cooke and Sheeran (2004) confirmed this expectation. They showed that participants with high affective-cognitive consistency demonstrated stronger attitude-behaviour consistency than participants with low affective-cognitive consistency. In particular, the study of Cooke and Sheeran (2004) underlined the utility of employing moderator variables to enhance the prediction of behaviour when using attitudes as predictors.

Similar distinctions between affective and cognitive components have been made recently in the realm of job satisfaction (Schleicher et al., 2004). The construct of job satisfaction is generally defined as "... a pleasurable or positive emotional state resulting from the appraisal of one's job or job experiences" (Locke, 1976, p. 1304). Saari and Judge (2004) reasoned that the importance of affect (or feeling) and of cognition (or thinking) is implicit in Locke's definition. It therefore appears that job satisfaction as an attitude can also be expressed in terms of affective and cognitive components and consequently also in terms of affective-cognitive consistency. Because affective-cognitive consistency has a relatively large and significant moderating effect in the relationship between an attitude and behaviour (Kraus, 1995; Cooke \& Sheeran, 2004), Schleicher et al. (2004), decided to investigate the influence of affective-cognitive consistency on the relationship between job satisfaction (an attitude) and job performance (subsequent behaviour). They hypothesised that ACC in job satisfaction attitudes (defined as the similarity between scores on an affectively based job satisfaction measure and a cognitively based job satisfaction measure) will moderate the job satisfaction-performance relationship. They selected the Overall Job Satisfaction Scale (OJS) (Brayfield \& Rothe, 1951) to represent the affective measure of job satisfaction and the short form of the Minnesota Satisfaction Questionnaire (MSQ) (Weiss, Dawis, England \& Lofquist, 1967) to represent the cognitive component of job satisfaction. Participants were rank-ordered separately in terms of their scores on the OJS and MSQ. Individuals' ACC was defined as the absolute value of the discrepancy between their positions in the two rankings. The higher the absolute value of the discrepancy was, the lower ACC (Schleicher et al., 2004). Job performance ratings were gathered on a 7-point behaviourally anchored rating scale (BARS) from the participants' supervisors. The results of two separate studies which included 66 employees from a wide range of industries in California and 84 urban firefighters employed in a metropolitan area in the southeast of America), confirmed that ACC is a significant moderator of the job satisfaction-job performance relationship (Schleicher et al., 2004). They found that the attitude-behaviour relationship was significantly stronger for employees with high ACC than for employees with low ACC.

In conclusion to their studies, Schleicher et al. (2004) expressed the hope that their research will provide the impetus to examine more critically how we currently conceptualise and operationalise attitudes in organisational behaviour research. They recommended that the study of ACC as a moderator of the job satisfaction-job performance relationship should be replicated and clarified by further studies using more varied samples.

The purpose of the present study was therefore to replicate and extend the research reported by Schleicher et al. (2004). To test their hypothesis in two separate studies, Schleicher et al. (2004) retained two job satisfaction questionnaires without modification as representing either an affective or a cognitive measure. They did this despite evidence that some items, on the basis of their contents, belonged to the opposite category/questionnaire.

In the present study, the results of the survey conducted by Schleicher et al. (2004) regarding the nature of the individual questionnaire items were used to compile an affective and a cognitive measure such that, on the basis of the known evidence, no grossly misclassified items were contained in each of the measures. By means of confirmatory factor analysis we subsequently investigated whether it made theoretical and empirical sense to assign the items of the two job satisfaction questionnaires to an affective and a cognitive scale respectively. These scales were then used to test the hypothesis that there is a stronger correlation between job satisfaction and job performance for respondents high in ACC than for participants low in ACC. This hypothesis implies that ACC is a significant moderator of the relationship between job satisfaction and job performance. The present research therefore was an extension of the studies conducted by Schleicher et al. (2004), because confirmation of the validity of splitting the questionnaires into affective and cognitive scales was sought. The testing of the research hypothesis involved a replication of the aforementioned authors' research in a South African context.

\section{METHOD}

\section{Participants}

The participants were 166 fulltime employees from a diverse slection of 43 South African companies and public institutions in Gauteng. There were 53 males and 113 females and their 
minimum educational level was Grade 12 . Their ages ranged from 20 to 62 with a mean age of 32,78 years $(S D=9,08)$. On average they had been employed by their present companies for $52,55$ months (SD $=69,14)$. Their current job levels were recorded as the following: Senior management or professional on a senior level $(\mathrm{N}=19,11,4 \%)$, middle management or professional on a middle level $(\mathrm{N}=50,30,1 \%)$, supervisor $(\mathrm{N}=36,21,7 \%)$, and administrative/technical position $(\mathrm{N}=61$, $36,7 \%)$.

\section{Measures}

Job satisfaction measures

Following the example of Schleicher et al. (2004), the Overall Job Satisfaction Scale (OJS) developed by Brayfield and Rothe (1951) and the short form of the Minnesota Satisfaction Questionnaire (MSQ) developed by Weiss, Dawis, England and Lofquist (1967) was used in the present study to measure job satisfaction. These measures were used, because the same criteria for selecting the job satisfaction measures were applicable in this study. The criteria were, firstly, that separate measures of affective and cognitive job satisfaction must be used and, secondly, that these measures must be equivalent with regard to presentation format (such as response format) and reliability. Schleicher et al. (2004) argued that the abovementioned measures were readily available and that they met the criteria to a greater extent than other available instruments.

With regard to the first criterion, Fisher (2000) and Weiss (2002) pointed out that pure measures of affective and cognitive job satisfaction do not exist. Although Schleicher et al. (2004) were aware that both the OJS and the MSQ probably measured both types of attitudes to some degree and that both contained items that measured affective and cognitive job satisfaction, they chose to use these measures unmodified. They justified their choice by explaining that they were able to demonstrate by means of survey results that the OJS is primarily affectively based, whereas the MSQ is primarily cognitively based. Moorman (1993) had also previously classified these scales in this way. He pointed out that the MSQ consists of items dealing with job conditions per se, whereas the OJS focuses on feelings or emotional reactions to the work. The Schleicher et al. (2004) survey comprised of $20 \mathrm{I} / \mathrm{O}$, social, and cognitive psychologists who had to rate each item as being primarily cognitive or affective. Following this they had to classify the full OJS and MSQ scales in the same way. All the psychologists categorised the OJS as more affective than cognitive and the MSQ as more cognitive than affective. Nevertheless, two items appeared to be misfits when the overall nature of the scale to which they belonged were evaluated by the psychologists. Item 3 of the OJS ("It seems that my friends are more interested in their jobs") was judged to be a cognitive item and Item 20 of the MSQ ("I am satisfied with the feeling of accomplishment that I get from the job") was judged to be an affective item.

For the present study we decided to use the information gathered by the survey data of Schleicher et al. (2004) to compile the affective and cognitive job satisfaction measures needed to test the hypothesis. It was hoped that 'purer' measures would result in this way rather than following the example of Schleicher et al. (2004). Item 20 was removed from the MSQ and added to the OJS items. Similarly, Item 3 of the OJS was used together with the remaining MSQ items. The modified OJS was then used in the analyses as an affective measure of job satisfaction, whereas the modified MSQ was used as a cognitive measure of job satisfaction. One of the goals of this research was to evaluate whether the modified OJS and MSQ indeed measured the constructs that they were expected to measure, to refine the measures if necessary, and also to determine the reliability of the modified measures.
With regard to the criterion of equivalence of presentation format and reliability, both the OJS and MSQ uses a 5-point Likert scale and consists of 18 and 20 items respectively. In the Schleicher et al. (2004) research, alpha coefficients of 0,92 and 0,88 were reported for the OJS, and 0,88 and 0,94 for the MSQ. They argued that the 38 items of the OJS and MSQ may be combined to provide an overall index of job satisfaction, because both measures have the same response format, acceptably high internal consistency, and are intended to measure job satisfaction. In their research alpha coefficients of 0,94 and 0,94 were obtained for the overall index. The means that Schleicher et al. (2004) obtained in their first study were $63,0(\mathrm{SD}=13,5)$ for the OJS, and $75,8(\mathrm{SD}=12,1)$ for the MSQ. In the present study the means for the unmodified versions of the measures were $66.18(\mathrm{SD}=10,38)$ for the OJS and 74,57 $(\mathrm{SD}=10,82)$ for the MSQ. The alpha coefficients were 0,88 for the OJS, 0,88 for the MSQ and 0,92 for the overall index. These results are reported in Table 1 .

TABLE 1

DECSRIPTIVE STATISTICS AND INTERCORRELATIONS FOR THE UNMODIFIED INDEPENDENT AND DEPENDENT VARIABLES $(\mathbf{N}=166)$

\begin{tabular}{lccccccc}
\hline & M & SD & Alpha & OJS & MSQ & Overall & Performance \\
\hline OJS & 66,18 & 10,38 & 0,88 & 1,00 & & & \\
MSQ & 74,57 & 10,82 & 0,88 & $0,54^{* *}$ & 1,00 & & \\
$\begin{array}{l}\text { Overall job } \\
\text { satisfaction }\end{array}$ & 140,75 & 18,55 & 0,92 & $0,87 * *$ & $0,88^{* *}$ & 1,00 & \\
$\begin{array}{l}\text { Job } \\
\text { performance }\end{array}$ & 7,02 & 1,40 & - & $0,28 * *$ & $0,20 * *$ & $0,27 * *$ & 1,00 \\
\hline
\end{tabular}

** $p<0,01$

Affective-cognitive consistency (ACC)

For each participant, a level of ACC was determined. Firstly, all the participants were rank-ordered in terms of their OJS scores, and thereafter in terms of their MSQ scores. The absolute value of the difference (or discrepancy) between the two ranks of any particular individual was taken as that individual's ACC level. A high absolute value indicates a low level of ACC, and vice versa. In the tables to follow a low ACC (low consistency) group means that the group obtained high difference scores, whereas a high ACC (high consistency) group means the group obtained low difference scores. Correlations involving the ACC variable were similarly adjusted. This procedure was also used by Chaiken and Baldwin (1981), Chaiken and Yates (1985), Norman (1975), Rosenberg and Hovland (1960) and Schleicher et al. (2004). The mean of the ACC scores obtained by Schleicher et al. (2004) in the first study was $10,9(\mathrm{SD}=9,9)$. They subsequently divided their participants into a high and a low ACC group by means of a median split. As expected, the correlation between scores on the OJS and the MSQ was very high for the high ACC group $(r=0,93)$, whereas it was low for the low ACC group $(r=0,26)$. The reliability of the ACC variable was 0,74 (Edwards, 2001). In the present study, the corresponding correlations were 0,91 and 0,07 when the unmodified versions of the OJS and MSQ were used and the mean ACC score was 36.90 ( $\mathrm{SD}=30,69)$. These correlations represent a check on the validity of splitting the respondents as described above, because by definition the correlation between scores on the OJS and the MSQ should be high for the high consistency (low discrepancy) group, and vice versa.

\section{Job performance}

The participants' direct supervisors were asked to provide an overall job performance rating on a 10-point scale ranging from 1 (most unsatisfactory) to 10 (highly satisfactory). The mean of the performance ratings was 7,02 (SD = 1,40) and $101(60,8 \%)$ of the respondents obtained job performance ratings of 7 or 8 (see Table 1). 


\section{Procedure}

Twenty one students who were registered for a master's degree in Industrial Psychology administered the questionnaires to fulltime employees of their choice that met the requirements of the study. They were also instructed to obtain the job performance ratings from the participants' supervisors. Each student had to collect data for at least six employees. There were only six missing values among the responses to the questionnaires and these values were replaced by the value of the 'undecided' option of the Likert scale, namely 3.

\section{RESULTS}

The analyses proceeded in four steps. Firstly, it was determined whether the modified OJS and MSQ were appropriate measures of affective and cognitive job satisfaction. This objective was achieved in several steps. Exploratory factor analyses (EFAs) were carried out on the modified OJS and MSQ separately to determine whether the items could meaningfully be grouped in parcels of items (see Bandalos, 2002; Comrey, 1988; De Bruin, 2004; Gorsuch, 1997; Little, Cunningham, Shahar \& Widaman, 2002) to serve as the input for a confirmatory factor analysis (CFA). The purpose of the CFA was to establish whether the modified OJS (including Item 20 of the MSQ) and the modified MSQ (including Item 3 of the OJS) measured two distinct aspects of job satisfaction, namely the affective and cognitive aspects as suggested by the survey results of Schleicher et al. (2004). Where indicated by the factor analytic results, the measures were modified in the second step of the analyses. Subsequently the psychometric properties of the resulting affective and cognitive measures were determined. All the items that remained in the two modified measures were then combined to represent the modified overall job satisfaction index and the psychometric properties of this measure were also computed. The third step of the analyses involved the computation of ACC scores based on the final modifications of the OJS and MSQ and splitting the sample into high and low ACC groups. In the fourth step, the relationship between job satisfaction and job performance was explored for the high and low consistency groups.

\section{Exploratory and confirmatory factor analyses}

Before an EFA was carried out on the modified OJS (excluding Item 3 and including Item 20 of the MSQ), diagnostic tests were conducted to establish whether the intercorrelation matrix met the requirements for a factor analysis. It was decided to omit Item 10 of the OJS, because of the low measure of sampling adequacy $(\mathrm{MSA}=0,23)$ that it yielded. When this was done, all of the individual item MSAs were larger than 0,60, the Kaiser-Meyer-Olkin MSA was equal to 0,91 and Bartlett's test of sphericity yielded a statistically significant approximate chi-square $\left[\chi^{2}(136)=1200,81\right.$, $\mathrm{p}<0,001]$. These values may be regarded as acceptable and it was decided to proceed with the factor analysis. The principal axis factoring method of extracting factors was carried out next, followed by varimax rotation of the factor axes. Three factors, accounting for $56.58 \%$ of the variance in the items, had eigenvalues larger than one. Seven items had high factor loadings on the first factor, namely Items $2,6,7,8,16,17$, and Item 20 of the MSQ. The contents of these items deal with the interest that respondents have in their jobs as opposed to being bored. Cronbach's alpha coefficient for this scale was equal to 0,87 . The second factor was defined by Items $1,5,12,13$ and 15 . These items measure the degree of enjoyment and satisfaction that one experiences in one's job. The alpha coefficient for this scale was equal to 0,74 . The third factor consisted of Items 4, 9, 11, 14 and 18 which focused on disliking or dreading one's job. In this instance the alpha coefficient was equal to 0,73 . Some of the items of the OJS are worded negatively and had to be reverse coded before total scores and internal consistency reliabilities could be computed (Items 4, 6, 8, 11, 14, 16, 18).

Before subjecting the intercorrelation matrix of the modified MSQ (excluding Item 20 and including Item 3 of the OJS) to an EFA, its suitability for factor analysis was examined. The MSA of Item 3 of the OJS (MSA $=0,50$ ) did not meet the required value of 0,60 (Tabachnik \& Fidell, 2001) and therefore this item was excluded from the factor analysis. After this was done, the Kaiser-Meyer-Olkin MSA was equal to 0,83 and Bartlett's test of sphericity yielded a statistically significant approximate chi-square $\left[\chi^{2}(171)=1971.12\right.$, $\mathrm{p}<0,001]$. A principal axis factor analysis followed by varimax rotation was subsequently carried out and yielded four factors with eigenvalues larger than one. These factors explained $55.52 \%$ of the variance of the items. The first factor consisted of Items $8,12,13$ and 14 that focused on job benefits. The alpha coefficient of this scale was equal to 0,70 , Items $1,3,4$, 9,10 and 11 had substantial loadings on the second factor that dealt with development of the self and one's sense of being valued in the work situation. This scale yielded an alpha equal to 0,75 . The third factor included Items $2,5,6,17,18$ and 19 which dealt with one's relations with one's supervisor and coworkers. This scale's Cronbach alpha was equal to 0,73. Only three items loaded on the fourth factor, namely Items 7,15 and 16. These items dealt with the extent to which one can work independently in the workplace and use one's own judgment. The associated alpha was equal to 0,78 .

It appeared that all of the subscales of the OJS and MSQ, formed on the basis of the EFA results, yielded satisfactory internal consistency reliabilities and could therefore serve as the input variables of a CFA. The reason for using parcels of items (the subscales) is that items violate the assumptions of factor analysis (Comrey, 1988; De Bruin, 2004). Furthermore, the use of the items themselves results in too many parameters to be estimated (or constraints to the hypothesised model), with the likely result of not obtaining a satisfactory fit during structural equation modeling (SEM).

The next step was to conduct a CFA using maximum likelihood estimation by means of the AMOS 5.0 software programme for SEM (Arbuckle, 2003). The purpose of the CFA was to establish whether the obtained data fitted a model that supports the notion of the modified OJS as being primarily an affective measure of job satisfaction and the modified MSQ as being primarily a cognitive measure of job satisfaction. The three OJS and four MSQ subscales were used as the measured variables to determine the validity of the hypothesised model. In the hypothesised model the latent variables were allowed to correlate with each other.

The model fit indices that were used, were the Model or Likelihood-ratio Chi-square, Chi-square/degrees of freedom ratio $\left(\chi^{2} / \mathrm{df}\right)$, Difference Chi-square comparing the fit between the constrained and hypothesised models $\left(\Delta \chi^{2}\right)$, Root Mean Squared Error of Approximation (RMSEA), PCLOSE of Browne and Cudeck (1993), Standardised Root Mean Residual (SRMR), Goodness of Fit Index (GFI), Adjusted Goodness of Fit Index (AGFI), Bentler-Bonett Normed Fit Index (NFI), Comparative Fit Index (CFI), and the Bollen Incremental Fit Index (IFI). The results of the CFA indicated that the fit of the data to the hypothesised model (Model 1) was reasonably good. The path diagram of the model and estimated parameters are presented in Figure 1 and the fit indices are reported in Table 2 . The magnitudes of the fit indices that are generally regarded as indicative of a good fit, are also presented in Table 2. All the factor loadings (standardized regression weights) were high as seen in Figure 1 , thereby confirming the substantial amount of variance shared between the various item parcels and their respective latent variables. The factor loadings varied from 0,65 to 0,90 , Some of the fit indices did not meet the accepted levels 
indicative of a good model fit (see Table 2), notably the statistically significant Model Chi-square $\left(\chi^{2}(13)=36,02, p=\right.$ $0,001)$. The hypothesis of an exact fit was therefore rejected. This result is obtained often in research and is usually ascribed to the size of the sample or lack of model fit (Byrne, 2001; Tabachnik \& Fidell, 2001), but in the present study the sample size was between 100 and 200 which is regarded as appropriate for the use of chi-square (Hair, Anderson, Tatham \& Black, 1998). The possibility that the model did not fit, remained the only viable explanation of the results. The RMSEA and PCLOSE values of 0,104 and 0,16 respectively, also did not reach acceptable magnitudes (Browne \& Cudeck, 1993).

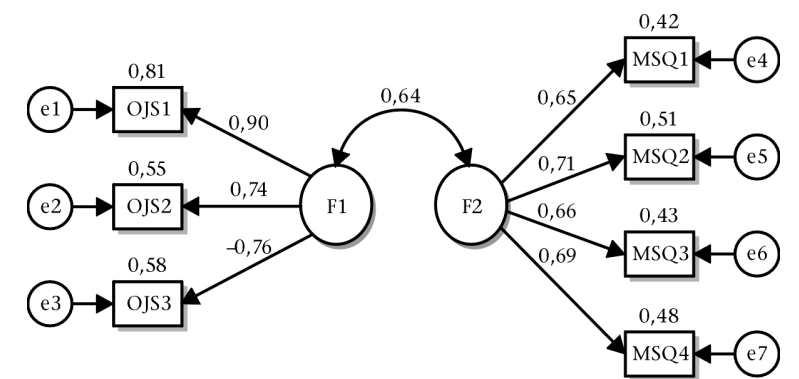

Figure 1: Standardised estimated parameters of Model 1 for the data

TABLE 2

FIT INDICES FOR MODELS 1 AND 2

\begin{tabular}{|c|c|c|c|}
\hline & Model 1 & Model 2 & Levels indicative of good fit \\
\hline $\begin{array}{l}\text { Model Chi-square } \\
\text { degrees of freedom }\end{array}$ & $\begin{array}{c}36,02 \\
13\end{array}$ & $\begin{array}{c}18,52 \\
12\end{array}$ & \\
\hline $\begin{array}{l}\text { degrees of freedom } \\
p \text { value }\end{array}$ & $\begin{array}{c}13 \\
0,001\end{array}$ & 0,101 & $\begin{array}{l}\text { p > 0,1 (Hair, Anderson, } \\
\text { Tatham \& Black, 1998) }\end{array}$ \\
\hline Chi-square/df ratio & 2,77 & 1,54 & $\begin{array}{l}\chi^{2} / \mathrm{df} \leq 2 \text { (Tabachnik \& } \\
\text { Fidell, 2001) }\end{array}$ \\
\hline$\Delta \chi^{2}(\mathrm{df})$ & & $17,5(\mathrm{p}<0,01)$ & $\begin{array}{c}\mathrm{p}<0,01 \text { (Tabachnik \& Fidell, } \\
\text { 2001) }\end{array}$ \\
\hline RMSEA & 0,104 & 0,057 & $\begin{array}{l}\leq 0,05 \text { to } 0,08 \text { (Browne } \& \\
\text { Cudeck, } 1993 \text { ) }\end{array}$ \\
\hline PCLOSE & 0,016 & 0,362 & $\begin{array}{l}\geq 0,05 \text { (Browne \& Cudeck, } \\
\text { 1993) }\end{array}$ \\
\hline SRMR & 0,055 & 0,046 & $\begin{array}{l}\leq 0,05 \text { (Hu \& Bentler, 1995; } \\
\text { 1999) }\end{array}$ \\
\hline GFI & 0,94 & 0,97 & $\begin{array}{l}\geq 0,90 \text { (Jöreskog \& Sörbom, } \\
1993 \text { ) }\end{array}$ \\
\hline AGFI & 0,87 & 0,93 & $\begin{array}{l}\geq 0,90 \text { (Jöreskog \& Sörbom, } \\
1993 \text { ) }\end{array}$ \\
\hline NFI & 0,92 & 0,96 & $\begin{array}{l}\geq 0,90 \text { (Bentler, 1990; Bentler } \\
\& \text { Bonett, 1980) }\end{array}$ \\
\hline CFI & 0,95 & 0,99 & $\begin{array}{l}\geq 0,95 \text { (Bentler, 1988; Hu \& } \\
\text { Bentler, 1999) }\end{array}$ \\
\hline IFI & 0,95 & 0,99 & $\geq 0,95$ (Bollen, 1989) \\
\hline
\end{tabular}

We then decided to investigate whether a modified model would provide a better fit for the data. The modification index associated with the covariance between the error term of the first OJS item parcel (e1) and the error term of the second MSQ parcel (e5) was large (M.I. = 15.46), suggesting substantial covariance between the first OJS parcel and the second MSQ parcel not accounted for by the covariance between the latent variables. It appears that the level of interest in one's job is correlated with one's feeling of self worth or being valued in the work situation. It was therefore decided to fit the data to a less constrained model (Model 2) that allows for a correlation between e1 and e5. A path diagram of Model 2 and the estimated parameters are presented in Figure 2. The fit indices are reported in Table 2.
This time all the fit indices met the minimum suggested magnitudes. The Model Chi-square was not statistically significant $\left[\chi^{2}(12)=18,52, p=0,101\right]$ and the Chi-square/df ratio was smaller than 2 . Models 1 and 2 are nested within each other and therefore a chi-square difference test could be performed to establish whether allowing for the additional correlation significantly improved the model. The Difference Chi-square comparing the fit between the constrained and hypothesised models $\left(\Delta \chi^{2}\right)$ was statistically significant, because $\Delta \chi^{2}(1)=17,50, \mathrm{p}<0,01$. It may be concluded that Model 2 is a significant improvement on Model 1.

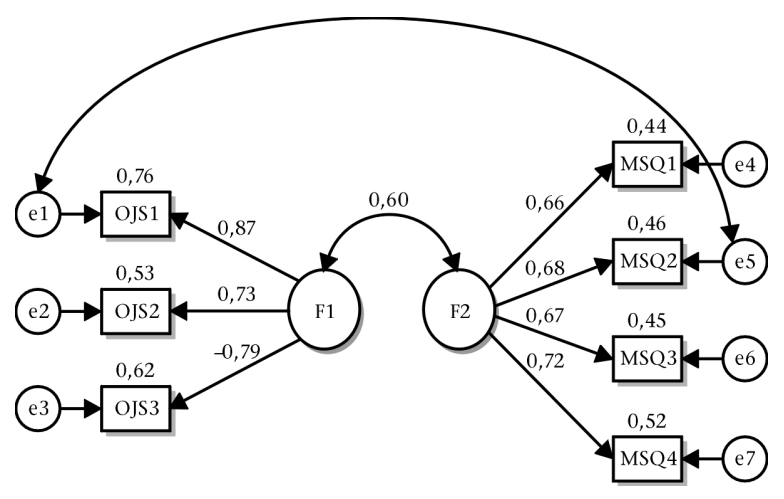

Place Figure 2 about here

Whenever model modifications are made, the results should be cross-validated with a new sample. When this is not possible, Tabachnik and Fidell (2001) recommended that the correlation between the estimated parameters of the original model and the final model be computed using only parameters common to both models. In the present study this correlation was $\mathrm{r}(15)=$ $0,997, p<0,001$. The magnitude of this correlation indicates that the relative sizes of the parameters were not substantially changed by the modification.

The results obtained with the EFAs and CFAs therefore supported the hypothesis that the OJS and MSQ primarily measured two distinct aspects of job satisfaction, namely the affective and cognitive components. A high correlation of 0,60 was obtained between the factors.

\section{Modified OJS and MSQ}

The OJS and MSQ were subsequently modified on the basis of the EFA and CFA results. The 17-item modified OJS, representing an affective measure, consisted of the OJS items excluding Items 3 and 10, and including Item 20 of the MSQ. Similarly, the 19item modified MSQ consisted of the MSQ items, excluding Item 20 , and represented a cognitive measure of job satisfaction. The psychometric properties of these modified measures were then determined. Next, all the items that remained in the two modified measures were combined to represent a 36-item modified overall job satisfaction index and the psychometric properties of this measure were also computed. The means, standard deviations, and alpha coefficients of these three measures are presented in Table 3. The internal consistency reliabilities were high and ranged from 0,87 to 0,92 . The correlation between the modified versions of the OJS and MSQ was equal to $0,54(\mathrm{p}<0,001)$.

\section{ACC scores}

ACC scores based on the participants' scores on the final modifications of the OJS and MSQ measures were computed as was described previously. Descriptive statistics for the ACC variable is reported in Table 3. The mean score was equal to 33,99 $(S D=30,81)$. In order to test the hypothesis that there is a stronger correlation between job satisfaction and job performance for respondents high in ACC than for participants low in ACC, the participants were split into high and low ACC groups. This was done in two ways. Firstly, a median-split was 
performed to yield two groups. Secondly, 25\% of the participants that obtained the highest ACC scores formed the high ACC group and $25 \%$ of the participants that obtained the lowest ACC scores formed the low ACC group. Descriptive statistics of the performance scores obtained by these groups are also presented in Table 3.

TABLE 3

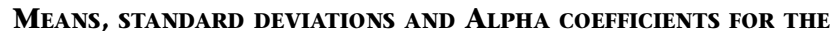
MODIFIED VERSIONS OF THE OJS, MSQ, OVERALL JOB STAISFACTION, ACC AND PERFORMANCE

\begin{tabular}{lccccccc}
\hline & N & M & SD & $\begin{array}{c}\text { No of } \\
\text { items }\end{array}$ & $\begin{array}{c}\text { Skew- } \\
\text { ness }\end{array}$ & Kurtosis & $\begin{array}{c}\text { Cronbach } \\
\alpha\end{array}$ \\
\hline Modified OJS & 166 & 63,55 & 10,54 & 17 & -1.14 & 1.96 & 0,91 \\
Modified MSQ & 166 & 70,70 & 10,24 & 19 & $-0,18$ & $-0,31$ & 0,87 \\
$\begin{array}{l}\text { Overall job } \\
\text { satisfaction }\end{array}$ & 166 & 134,25 & 18,20 & 36 & $-0,51$ & 0,33 & 0,92 \\
ACC & 166 & 33,99 & 30,81 & & 1,17 & 0,74 & \\
$\begin{array}{l}\text { Performance for } \\
\text { low ACC group }\end{array}$ & 80 & 6,96 & 1,58 & & $-1,04$ & 1,71 & \\
$\begin{array}{l}\text { Performance for } \\
\text { high ACC group }\end{array}$ & 86 & 7,07 & 1,22 & & $-0,66$ & 0,33 & \\
$\begin{array}{l}\text { Performance for } \\
\text { low 25\% ACC }\end{array}$ & 41 & 6,65 & 1,60 & & $-0,51$ & $-0,77$ & \\
$\begin{array}{l}\text { Performance for } \\
\text { high 25\% ACC }\end{array}$ & 41 & 7,17 & 1,26 & & & & \\
\hline
\end{tabular}

Relationship between job satisfaction and performance In the final step of the analyses the relationships between job satisfaction and job performance for the high and low ACC groups were examined to test the hypothesis that ACC is a moderator of the job satisfaction-performance relationship. The correlations between the modified job satisfaction variables, ACC and performance are reported in Table 4. ACC was not correlated with any of the job satisfaction measures, because the correlations ranged from $-0,05$ to 0,06 . ACC was also not correlated with performance for the high consistency groups, but in the case of the low consistency groups correlations of 0,36 and 0,47 were obtained.

TABLE 4

CORRELATIONS BETWEEN THE MODIFIED STUDY VARIABLES

\begin{tabular}{llll}
\hline & $\begin{array}{c}\text { Modified } \\
\text { OJS }\end{array}$ & $\begin{array}{c}\text { Modified } \\
\text { MSQ }\end{array}$ & $\begin{array}{c}\text { Overall } \\
\text { Job } \\
\text { Satisfaction }\end{array}$ \\
\hline Modified OJS & 1,00 & & \\
Modified MSQ & $0,54^{* *}$ & 1,00 & \\
Overall Job Satisfaction & $0,88^{* *}$ & $0,87^{* *}$ & 1,00 \\
ACC & $-0,05$ & 0,06 & 0,003 \\
Performance & $0,25^{* *}$ & $0,20^{*}$ & $0,26^{* *}$ \\
Performance for low ACC group & 0,15 & 0,14 & 0,20 \\
Performance for high ACC group & $0,37^{* *}$ & $0,26^{*}$ & $0,32^{* *}$ \\
Performance for low 25\% ACC group & $-0,04$ & 0,15 & 0,12 \\
Performance for high 25\% ACC group & $0,47^{* *}$ & $0,42^{* *}$ & $0,45^{* *}$ \\
\hline
\end{tabular}

** $\mathrm{p}<0,01 \quad * \mathrm{p}<0,05$
The correlations between job performance and the modified OJS, MSQ and job satisfaction composite were equal to 0,25 $(\mathrm{p}=0,001), 0,20(\mathrm{p}=0,011)$, and $0,26(\mathrm{p}=0,001)$ respectively (see Table 4). These correlations were statistically significant and represented small to medium effect sizes. However, when the sample was split into high and low consistency groups, the results were much more pronounced, because the correlations were markedly lower for the low consistency groups than for the high consistency groups. For the low consistency groups none of the satisfaction-performance correlations were statistically significant and they ranged from $-0,04$ to 0,20 , For the high consistency groups all of the correlations were statistically significant, approached medium to large effect sizes, and ranged from 0,26 to 0,47 .

As expected, the largest correlation differences between the low and high consistency groups were obtained between the lower and upper $25 \%$ groups. For the modified OJS the correlations were $-0,04(p=0,791)$ and $0,47(p=0,002)$. Using a one-tailed hypothesis test, the difference between these two correlations was statistically significant, $\mathrm{z}=2,50, \mathrm{p}<0,01$. For the modified MSQ the correlations were $0,15(p=0,35)$ and $0,42(p=0,007)$. The difference between these correlations was not statistically significant, $\mathrm{z}=1,36, \mathrm{p}>0,05$. And finally, for the modified overall job satisfaction measure, the correlations were $0,12(p=$ $0,45)$ for the low consistency group and $0,45(p=0,003)$ for the high consistency group. Once more the difference between these correlations was statistically significant, $z=1,68, p<0,05$. In the case of the groups formed by means of a median split, the correlations did not differ statistically significantly despite the apparent differences in the magnitudes of the correlations. Z values of $1,52,0,82$ and 0,82 were obtained for the modified OJS, the MSQ and the job satisfaction composite. The above results support the research hypothesis in the case of the modified OJS and the job satisfaction composite for the upper and lower $25 \%$ groups when the statistical significance of differences between the correlations is considered. However, bearing in mind the obtained effect sizes and the influence that the reduced sample sizes for the sample splits had on the $\mathrm{z}$ tests, one may conclude that considerable support for the research hypothesis was obtained.

\section{DISCUSSION}

Job satisfaction and job performance are among the variables most commonly studied by industrial-organisational psychologists. Although it makes logical and theoretical sense that these two variables should be strongly positively correlated as seen from a social psychological viewpoint, the majority of research findings have shown the opposite, namely that they are unrelated (Judge et al., 2001). Such results have led to the common belief among industrial-organisational psychologists that the most prominent attitude about the job (job satisfaction) is unrelated to the most prominent job behaviour (job performance). Several explanations have been offered in the literature for these results (Judge et al., 2001; Organ, 1988; Saari \& Judge, 2004), among others that reviews about the relationship have been misinterpreted. The current study presented an attempt to observe the relationship by changing the manner in which job satisfaction has been previously conceptualized and operationalised. Specifically, an additional component of attitudes, namely respondents' ACC, was included in the hope that more light would be shed on the satisfactionperformance relationship. The purpose of the study was therefore to find support for the hypothesis that attitudinal consistency affects the strength of the relationship between job satisfaction and job performance.

The present research had two primary objectives. The first objective was to assess whether modified versions of the Overall Job Satisfaction Scale (Brayfield \& Rothe, 1951) and the short form of the Minnesota Satisfaction Questionnaire (Weiss et al., 
1967) could be regarded as being affective and cognitive measures of job satisfaction respectively. The results obtained by means of exploratory and confirmatory factor analyses supported the hypothesis that the OJS primarily measured the affective and the MSQ the cognitive aspects of job satisfaction. The OJS and MSQ were modified on the basis of the EFA and CFA results resulting in a 17-item modified OJS and a 19-item modified MSQ. Both of these measures were highly internally consistent. Overall job satisfaction was measured by means of a questionnaire that was a composite of the modified OJS and MSQ measures.

Respondents' scores on the modified OJS and MSQ were used to form groups that were high or low in affective-cognitive consistency to test the hypothesis that there is a stronger correlation between job satisfaction and job performance for respondents high in ACC than for participants low in ACC, the second objective of this study. The results of the study showed that in the case of employees who displayed high affective-cognitive consistency regarding their job satisfaction attitudes, medium to large positive correlations between satisfaction and performance were obtained (Cohen, 1988). This relationship held for affective, cognitive and composite measures of job satisfaction. These results were in sharp contrast to the non-significant correlations recorded for the low ACC groups.

The findings of the study therefore supported the hypothesis that ACC is a significant moderator of the relationship between job satisfaction and job performance as was also found by Schleicher et al. (2004). The results of the present study were somewhat less dramatic than those obtained by Schleicher et al. (2004) who found correlations of $-0,03$ and $-0,11$ between overall satisfaction and performance for the low ACC groups, as against 0,57 and 0,54 for the high ACC groups, but the results were nonetheless equally convincing. An explanation for the differences may be that the reliability and/or validity of the job performance measures were higher in the case of the Schleicher et al. (2004) studies. It is worth noting that similar correlations were found in Kraus's (1995) meta-analysis concerning the effect of ACC on attitude-behaviour relations overall. The present findings therefore confirmed the importance of investigating moderator variables, such as the affectivecognitive consistency of job satisfaction attitudes, in trying to understand the conditions under which job satisfaction and job performance are related.

Positive aspects of the study were that the sample size was larger than that used in the two Schleicher et al. (2004) studies and that the results were similar. One may therefore regard the present study as a successful replication of the kind recommended by these researchers. Furthermore, the sample used represented a diverse group of full-time employees from 43 different companies and public institutions.

The study was also an extension of the Schleicher et al. (2004) studies, because more extensive analyses were performed to assess the construct validity of the cognitive and affective measures of job satisfaction. Although the factor-analytic results indicated that two distinct concepts were being measured, the correlation between the modified versions of the OJS and MSQ was substantial $(\mathrm{r}=0,54)$. In support of Schleicher et al. (2004), we therefore caution that these measures cannot be assumed to be 'pure' measures of affective and cognitive job satisfaction, because all such measures tend to fall along a continuum. Rather, the OJS should be regarded as 'more affective' than the MSQ, and the MSQ as 'more cognitive' than the OJS. These measures were used, because they appeared to be the best ones available that met the requirements of the study. Use of the modified versions in this study presented an attempt to incorporate the findings of Schleicher et al. (2004) as well as the empirical results of the current study to create even 'purer' cognitive and affective measures for the purposes of the study.
We do not thereby suggest that the modified versions are better measures of job satisfaction than the unmodified versions. A further complication is the synergistic relation between the two components of attitudes, because it is unlikely that affect will ever be uncontaminated by cognition, nor that cognition can be uncontaminated by affect (Eagly, Mladinic, \& Otto, 1994; Weiss, 2002).

Several possibilities for future research emanate from this study and those of Schleicher et al. (2004). Firstly, the causal and perhaps reciprocal nature of the satisfaction-performance relationship should be tested and the role of the ACC moderator determined by means of causal modeling. Secondly, it is not yet known what causes ACC or the strength of attitudes in the workplace. Thirdly, although the components of attitudes and the attitude-behaviour relation have been studied in many areas of psychology, the same is not true for industrial-organisational psychology. The role of ACC in job-related attitudes other than job satisfaction, for instance in organisational and occupational commitment, are avenues for further research. Similarly, criteria other than job performance (such as organisational citizenship behaviour, absenteeism and turnover) need to be studied to clarify further the role of ACC. And finally, it is recommended that the modified versions of the OJS and MSQ should be used in subsequent studies with various other samples to confirm their validity as affective and cognitive measures of job satisfaction in a South African context.

\section{ACKNOWLEDGEMENT}

The authors wish to thank Riëtte Eiselen and Wilhelm Koster of the Statistical Consultation Service of the University of Johannesburg for conducting the AMOS and SPSS computations.

\section{REFERENCES}

Arbuckle, J.L. (2003). AMOS 5.0 [Computer software]. Chicago: Smallwaters.

Baker, W.K. (2004). Antecedents and consequences of job satisfaction: Testing a comprehensive model using integrated methodology. The Journal of Applied Business Research, 20 (3), 31-43.

Bandalos, D.L. (2002). The effect of item parcelling on goodnessof-fit and parameter estimate bias in structural equation modelling. Structural Equation Modeling, 9, 78-102.

Bassett, G. (1994). The case against job satisfaction. Business Horizons, 9, 61-68.

Bentler, P.M. (1988). Causal modeling via structural equation systems. In J.R. Nesselroade \& R.B. Cattell (Eds.), Handbook of multivariate experimental psychology ( $2^{\text {nd }}$ edition, $p$ p. 317335). New York: Plenum.

Bentler, P.M. (1990). Comparative fit indexes in structural models. Psychological Bulletin, 107, 238-246.

Bentler, P.M. \& Bonett, D.G. (1980). Significance tests and goodness of fit in the analysis of covariance structures. Psychological Bulletin, 88, 588-606.

Bollen, K.A. (1989). A new incremental fit index for general structural models. Sociological Methods and Research, 17, 303316.

Brayfield, A.H. \& Rothe, H.F. (1951). An index of job satisfaction. Journal of Applied Psychology, 35, 307-311.

Browne, M.W. \& Cudeck, R. (1993). Alternative ways of assessing model fit. In K.A Bollen \& J.S Long (Eds.), Testing structural equation models (pp. 445-455). Newbury Park, CA: Sage.

Byrne, B.M. (2001). Structural equation modeling with AMOS. London: Lawrence Erlbaum.

Chaiken, S. \& Baldwin, M.W. (1981). Affective-cognitive consistency and the effect of salient behavioral information on the self-perception of attitudes. Journal of Personality and Social Psychology, 41, 1-12. 
Chaiken, S. \& Yates, S. (1985). Affective-cognitive consistency and thought-induced attitude polarization. Journal of Personality and Social Psychology, 49, 1470-1481.

Cohen, J. (1988). Statistical power analysis for the behavioral sciences ( $2^{\text {nd }}$ ed.). Hillsdale, NJ: Erlbaum.

Cooke, R. \& Sheeran, P. (2004). Moderation of cognitionintention and cognition-behaviour relations: A metaanalysis of properties of variables from the theory of planned behaviour. British Journal of Social Psychology, 43, 159-186.

Comrey, A.L. (1988). Factor analytic methods of scale development in personality and clinical psychology. Journal of Consulting and Clinical Psychology, 56, 754-761.

Cotton, J.L. \& Tuttle, J.M. (1986). Employee turnover: A metaanalysis and review with implications for research. Academy of Management Review, 7, 117-123.

De Bruin, G.P. (2004). Problems with the factor analysis of items: Solutions based on item response theory and item parcelling. South African Journal of Industrial Psychology, 30 (4), 16-26.

Eagly, A.H., Mladinic, A. \& Otto, S. (1994). Cognitive and affective bases of attitudes toward social groups and social policies. Journal of Experimental Social Psychology, 30, 113137.

Edwards, J.R. (2001). Alternatives to difference scores: Polynomial regression analysis and response surface methodology. In F. Drasgow \& N. Schmitt (Eds.), Advances in measurement and data analysis (pp. 350-401). San Francisco: Jossey-Bass.

Fisher, C.D. (2000). Mood and emotions while working: Missing pieces of job satisfaction? Journal of Organizational Behavior, 21, 185-202.

Gorsuch, R.L. (1997). Exploratory factor analysis: Its role in item analysis. Journal of Personality Assessment, 68, 532-560,

Hair, J.F., Anderson, R.E., Tatham, R.L. \& Black, W.C. (1998). Multivariate data analysis (5 $5^{\text {th }}$ ed.). Upper Saddle River, NJ: Prentice-Hall.

Harter, J.K., Schmidt, F.L. \& Keyes, C.L.M. (2003). Well-being in the workplace and its relationship to business outcomes: A review of the Gallup studies. In C.L.M. Keyes \& J. Haidt (Eds.), Flourishing: Positive Psychology and the life well-lived (pp. 205-224). Washington, DC: American Psychological Association.

Harter, J.K., Schmidt, F.L. \& Hayes, T.L. (2002). Business-unitlevel relationship between employee satisfaction, employee engagement, and business outcomes: A meta-analysis. Journal of Applied Psychology, 87, 268-279.

Hoole, C. \& Vermeulen, L.P. (2003). Job satisfaction among South African Aircraft Pilots. South African Journal of Industrial Psychology, 29 (1), 52-57.

Hu, L-T. \& Bentler, P.M. (1995). Evaluating model fit. In R.H. Hoyle (Ed.), Structural equation modeling: Concepts, issues, and applications (pp. 76-99). Thousand Oaks, CA: Sage.

Hu, L-T. \& Bentler, P.M. (1999). Cutoff criteria for fit indexes in covariance structure analysis: Conventional criteria versus new alternatives. Structural Equation Modeling: A Multidisciplinary Journal, 6, 1-55.

Iaffaldano, M.T. \& Muchinsky, P.M. (1985). Job satisfaction and job performance: A meta-analysis. Psychological Bulletin, 97, 251-273.

Isen, A.M. \& Baron, R.A. (1991). Positive affect as a factor in organizational behavior. Research in Organizational Behavior, $13,1-53$

Jöreskog, K.G. \& Sörbom, D. (1993). Testing structural equation models. In K.A. Bollen \& J.S. Long (Eds.), Testing structural equation models (pp. 294-316). Newbury Park, CA: Sage.

Judge, T.A., Thoresen, C.J., Bono, J.E. \& Patton, G.K. (2001). The job satisfaction-job performance relationship: A qualitative and quantitative review. Psychological Bulletin, 127, 376-407.

Kraus, S.J. (1995). Attitudes and the prediction of behavior: A meta-analysis of the empirical literature. Personality and Social Psychology Bulletin, 21 (1), 58-75.

Little, T.D., Cunningham, W.A., Shahar, G. \& Widaman, K.F. (2002). To parcel or not to parcel: Exploring the question, weighing the merits. Structural Equation Modeling, 9, 151173.

Locke, E.A. (1976). The nature and causes of job satisfaction. In M.D. Dunnette (Ed.), Hanbook of Industrial and Organizational Psychology (pp. 1297-1349). Chicago: Rand McNally.

Moorman, R.H. (1993). The influence of cognitive and affective based job satisfaction measures on the relationship between satisfaction and organizational citizenship behavior. Human Relations, 46, 759-776.

Norman, R. (1975). Affective-cognitive consistency, attitudes, conformity, and behavior. Journal of Personality and Social Psychology, 32, 83-91.

Orban, J.A. \& Harris, J.A. (1998). Relation of unit management attitudes and robust unit performance. Journal of Business and Psychology, 12 (3), 379-385.

Organ, D.W. (1988). A restatement of the satisfactionperformance hypothesis. Journal of Management, 14, 547-557.

Pretorius, A.A.S. \& Roodt, G. (2004). Die verband tussen werknemertevredenheid en organisasieverbondenheid. South African Journal of Industrial Psychology, 30 (3), 65-74.

Rosenberg, M.J. (1960). A structural theory of attitude dynamics. Public Opinion Quarterly, 24, 319-341.

Rosenberg, M.J. (1968). Hedonism, inauthenticity, and other goals toward expansion of a consistency theory. In R.P. Abelson, E. Aronson, W.J. McGuire, T.M. Newcomb, M.J. Rosenberg, \& P.H. Tannebaum (Eds.), Theories of cognitive consistency: A sourcebook (pp. 73-111). Chicago: Rand McNally.

Rosenberg, M.J.A. \& Hovland, C.I. (1960). Cognitive, affective, and behavioral components of attitudes. In C.I. Hovland \& M.J. Rosenberg (Eds.), Attitude organization and change (pp. 1-14). New Haven, CT: Yale University Press.

Rothmann, S. (2001). Sense of coherence, locus of control, selfefficacy and job satisfaction. South African Journal of Economic and Management Sciences, 4 (1), 41-65.

Saari, L.M. \& Judge, T.A. (2004). Employee attitudes and job satisfaction. Human Resource Management, 43 (4), 395-407.

Schleicher, D.J., Watt, J.D. \& Greguras, G.J. (2004). Reexamining the job satisfaction-performance relationship: The complexity of attitudes. Journal of Applied Psychology, 89, $165-177$

Schneider, B., Hanges, P.J., Smith, D.B. \& Salvaggio, A.N. (2003) Which comes first: Employee attitudes or organizational, financial and market performance? Journal of Applied Psychology, 88 (5), 836-851.

Scott, K.D. \& Taylor, G.S. (1985). An examination of conflicting findings on the relationship between job satisfaction and absenteeism: A meta-analysis. Academy of Management Journal, 28, 599-612.

Spector, P.E. (1997). Job satisfaction: Application, assessment, cause and consequences. Thousand Oaks, CA: Sage.

Steel, R.P. \& Rentsch, J.R. (1997). The dispositional model of job attitudes revisited: Findings of a 10-year study. Journal of Applied Psychology, 82, 873-879.

Tabachnick, B.G. \& Fidell, L.S. (2001). Using multivariate statistics (4th ed.). Boston, MA: Allyn \& Bacon.

Weiss, D.J., Dawis, R.V., England, G.W. \& Lofquist, L.H. (1967). Manual for the Minnesota Satisfaction Questionnaire. Minnesota studies for vocational rehabilitation (No. XXII). Minneapolis: Industrial Relations Center, University of Minnesota.

Weiss, H.M. (2002). Deconstructing job satisfaction: Separating evaluations, beliefs, and affective experiences. Human Resource Management Review, 12, 1-22. 